\title{
PENGARUH EFIKASI DIRI DAN PENDIDIKAN TERHADAP INTENSI KEWIRAUSAHAAN DENGAN LINGKUNGAN SOSIAL SEBAGAI VARIABEL MODERASI
}

\author{
Andrew Bryan \\ Program Studi Magister Manajemen Universitas Tarumanagara \\ Andrewbryanho@gmail.com
}

\begin{abstract}
This study aims to determine the effect of self efficacy and education on the intention of entrepreneurship with social environment as a moderation variable. Methods of data collection using questionnaires. The respondents of this research are students of Faculty of Economics University Tarumanagara. The study was conducted in May 2018. The method of data analysis using multiple regression with the moderation variable. The results of the study conclude that self efficacy and education have a positive effect on the intention of entrepreneurship. Social environment variables deserve to be a moderation variable because there is an effect of self efficacy and education on the intention of entrepreneurship moderated by social environment.
\end{abstract}

Keyword: self efficacy, education, intention of entrepreneurship, social environment

\section{LATAR BELAKANG}

Pertumbuhan jumlah tenaga kerja terus meningkat. Meningkatnya jumlah tenaga kerja kurang diimbangi dengan ketersediaan lapangan kerja. Oleh karena melimpahnya pencari kerja dan sedikitnya lowongan kerja, perusahaan yang membutuhkan karyawan cenderung menetapkan standar kualitas sumber daya manusia yang cukup tinggi. Kualitas sumber daya manusia menentukan keberhasilan kerja dan perolehan pekerjaan. Berdasarkan permasalahan tersebut maka pengembangan sikap wirausaha sangat diperlukan dalam menanggapi kurangnya lapangan pekerjaan. Seorang wirausahawan diharapkan mampu membuka lapangan pekerjaan bagi orang lain. Manfaat ini diharapkan mampu menekan laju pengangguran di Indonesia.

Studi mengenai kewirausahaan merupakan studi yang sangat penting dan menarik. Studi ini umumnya mencoba mencari faktor-faktor yang mempengaruhi pembentukan seorang wirausahawan. Seorang wirausahawan merupakan seorang yang penuh dengan pemikiran yang luas, tekad yang kuat dan keberanian yang tinggi. Studi mengenai kewirausahaan berarti studi yang membahas faktor-faktor yang membentuk manusia yang memiliki sifat tersebut. Tidak mudah membentuk manusia untuk memiliki sifat kewirausahaan karena tiap orang memiliki karakteristik yang berbeda.

Penelitian Ekpe dan Mat (2012) menyatakan bahwa faktor yang mempengaruhi intensi kewirausahaan adalah efikasi diri, pendidikan, dan lingkungan sosial. Berdasarkan latar belakang tersebut penelitian ini diharapkan mampu memberikan gambaran mengenai faktor yang mempengaruhi intensi kewirausahaan karena intensi kewirausahaan merupakan solusi dalam mengatasi jumlah pengangguran di Indonesia.

Bandura dalam Sarwono dan Arif (2013) menyatakan bahwa efikasi diri adalah kepercayaan seseorang atas kemampuan dirinya untuk meyelesaikan suatu pekerjaan. Tung dan Yin (2011) mendefinisikan pendidikan sebagai suatu usaha yang diberikan untuk mendukung mahasiswa meningkatkan minat berwirausaha. Ekpe dan Mat (2012) mendefinisikan lingkungan sosial sebagai ikatan sosial, model peran, dan penasihat yang 
menyediakan akses informasi dan sumber daya yang dibutuhkan untuk aktivitas kewirausahaan. Menurut Rano (2012) intensi kewirausahaan sebagai pencapaian kemajuan usahanya, kesediaan menanggung macam-macam risiko berkaitan dengan tindakan berusaha yang dilakukannya, bersedia menempuh jalur dan cara baru, kesediaan untuk hidup hemat, kesediaan dari belajar yang dialaminya.

\section{TINJAUAN PUSTAKA}

\section{Kewirausahaan}

Menurut Coulter (Yuyus Suryana dan Kartib Bayu, 2011: 25), "kewirausahaan sering dikaitkan dengan proses, pembentukan atau pertumbuhan suatu bisnis baru yang berorientasi pada pemerolehan keuntungan, penciptaan nilai, dan pembentukan produk atau jasa baru yang unik dan inovatif". Linan (2004: 115) menyebutkan "intensi merupakan elemen yang fundamental yang dapat menjelaskan sebuah perilaku". Armitage dan Corner (1999: 13) mengungkapkan bahwa "sebagai predictor perilaku, intensi dipandang sebagai motivasi yang sangat diperlukan ketika seseorang akan melakukan perilaku tertentu". Choo dan Wong (sebagaimana dikutip dari Nurul Indarti dan Rokhima Rostiani, 2008: 4) menyatakan bahwa "intensi dapat dijadikan sebagai pendekatan dasar yang masuk akal untuk memahami siapa-siapa yang akan menjadi wirausaha".

\section{Intensi kewirausahaan}

Rano (2012) mendefinisikan intensi kewirausahaan sebagai pencapaian kemajuan usahanya, kesediaan menanggung macam-macam risiko berkaitan dengan tindakan berusaha yang dilakukannya, bersedia menempuh jalur dan cara baru, kesediaan untuk hidup hemat, kesediaan dari belajar yang dialaminya. Menurut Linan dan Leon dalam Eka (2012) intensi kewirausahaan adalah: "the individual's decision to become an entrepreneur". Berdasarkan definisi tersebut maka intensi kewirausahaan dapat diartikan sebagai keinginan bekerja keras untuk menjadi wirausaha.

\section{Efikasi Diri (Self Efficacy)}

Menurut King (2012:153), "efikasi diri adalah keyakinan bahwa seseorang dapat menguasai suatu situasi dan menghasilkan berbagai hasil positif". Lebih lanjut, King (2012:53) menjelaskan bahwa "efikasi diri membantu orang-orang dalam berbagai situasi yang tidak memuaskan dan mendorong mereka untuk meyakini bahwa mereka dapat berhasil". Menurut Alwisol (2011: 287), "efikasi diri adalah persepsi diri sendiri mengenai seberapa bagus diri dapat berfungsi dalam situasi tertentu. Efikasi diri berhubungan dengan keyakinan bahwa diri memiliki kemampuan melakukan tindakan yang diharapkan". Efikasi diri berbeda dengan cita-cita karena cita-cita menggambarkan sesuatu yang ideal yang seharusnya dapat dicapai, sedangkan efikasi menggambarkan penilaian kemampuan diri.

Bandura dalam Sarwono dan Arif (2013) menyatakan bahwa efikasi diri adalah kepercayaan seseorang atas kemampuan dirinya untuk meyelesaikan suatu pekerjaan. Menurut Indarti dan Rostiani dalam Retno, Susilaningsih, dan Sri (2013) efikasi diri adalah kepercayaan seseorang atas kemampuannya untuk menyelesaikan suatu pekerjaan. Menurut Lee et. al. (2011) "Self-efficacy is a person's judgment of his/her ability to execute a targeted behavior". Berdasarkan definisi tersebut maka dapat disimpulkan bahwa efikasi diri adalah penilaian seseorang atas kemampuan dirinya dalam melakukan pekerjaan.

Efikasi diri merupakan kondisi dimana individu percaya bahwa perilaku untuk berwirausaha mudah atau dapat dilakukan. Efikasi diri dalam konteks bisnis merupakan sikap yang berasal dari keyakinan diri individu dan persepsi terhadap kompetensi dalam melakukan bisnis. Penilaian efikasi diri juga menentukan seberapa besar usaha yang dikeluarkan dan 
seberapa lama individu bertahan dalam menghadapi rintangan dan pengalaman yang menyakitkan. Semakin kuat persepsi efikasi diri semakin giat dan tekun usaha-usahanya. Dengan demikian, efikasi diri akan karir seseorang dapat menjadi faktor penting dalam penentuan apakah intensi kewirausahaan seseorang sudah terbentuk pada tahapan awal seseorang memulai karirnya. Intensi kewirausahaan dipengaruhi efikasi diri, dimana pengaruhnya positif, semakin tinggi dukungan pada mahasiswa, maka semakin tinggi niat untuk berwirausaha, demikian pula semakin tinggi rasa percaya diri dan kematangan mental, maka semakin tinggi pula niat berwirausaha (Sri, 2013). Berdasarkan uraian tersebut maka hipotesis penelitian:

$\mathrm{H}_{1}$ : $\quad$ Terdapat pengaruh efikasi diri terhadap intensi kewirausahaan.

\section{Pendidikan}

Pendidikan kewirausahaan merupakan suatu disiplin ilmu yang mempelajari nilai, kemampuan dan perilaku dalam menghadapi berbagai tantangan hidup. Kewirausahaan diajarkan sebagi suatu disiplin ilmu karena kewirausahaan memiliki badan pengetahuan yang utuh dan nyata, memiliki dua konsep yaitu venture start-up dan venture growth serta memiliki objek tersendiri yaitu kemampuan menciptakan sesuatu (Suryana, 2009). Perguruan tinggi melalui pendidikan kewirausahan adalah faktor penting di sebuah negara untuk mendorong pertumbuhan (Zimmerer, 2008).

Menurut Retno dan Trisnadi (2012) pendidikan adalah suatu usaha membentuk pola pikir, sikap, dan perilaku pada mahasiswa menjadi seorang wirausahawan (entrepreneur) sejati sehingga mengarahkan mereka untuk memilih berwirausaha sebagai pilihan karir. Tung dan Yin (2011) mendefinisikan pendidikan sebagai suatu usaha yang diberikan untuk mendukung mahasiswa meningkatkan minat berwirausaha. Menurut Sang, Daesung, dan Seong (2005) pendidikan adalah pembekalan motivasi, pengetahuan, dan keterampilan mahasiswa untuk berwirausaha. Berdasarkan definisi tersebut maka dapat disimpulkan bahwa pendidikan adalah suatu usaha membentuk pola pikir, sikap, dan perilaku pada mahasiswa dan pembekalan motivasi, pengetahuan, dan keterampilan bagi mahasiswa untuk berwirausaha.

Menurut Tung dan Yin (2011), pendidikan akan meningkatkan efikasi kewirausahaan mahasiswa seperti mencari peluang, menggabungkan sumber daya, dan memimpin bisnis dengan sukses melalui sikap, pengetahuan dan keterampilan yang diberikan kepada mereka. Pendidikan juga dapat meningkatkan efikasi kewirausahaan mahasiswa melalui kegiatan pembelajaran, pengembangan rencana bisnis, menjalankan usaha kecil yang nyata, dan meningkatkan keinginan mereka untuk memulai usaha baru. Kewirausahaan terkait mata kuliah dan pelatihan diperlukan untuk meningkatkan niat kewirausahaan mahasiswa dan efikasi kewirausahaan. Pendidikan tinggi secara berbeda-beda mempersiapkan mahasiswa dengan pengetahuan yang berbeda yang dapat bertindak sebagai peran menengahi kemampuan kewirausahaan mahasiswa. Berdasarkan uraian tersebut maka hipotesis penelitian:

$\mathrm{H}_{2}$ : Terdapat pengaruh pendidikan terhadap intensi kewirausahaan.

\section{Lingkungan Sosial}

Menurut Ekpe dan Mat (2012) lingkungan sosial adalah ikatan sosial, pengaruh teman dan keluarga, role model dan penasihat. Menurut Tung dan Yin (2011) lingkungan sosial adalah figur yang merupakan motivator untuk berwirausaha. Menurut Van Auken dalam Tung dan Yin (2011) lingkungan sosial adalah figur yang menyediakan pengalaman positif yang mempengaruhi intensi berwirausaha. Kewirausahaan beroperasi dalam suatu lingkungan yang dinamis, yang pada umumnya tidak dapat dikendalikan oleh wirausaha itu sendiri. Lingkungan kewirausahaan itu sendiri sangat luas, sehingga penelitian yang dilakukan 
peneliti-peneliti terdahulu juga bervariasi secara luas. Berdasarkan definisi tersebut maka dapat disimpulkan bahwa lingkungan sosial adalah ikatan sosial, pengaruh teman dan keluarga, role model dan penasihat yang merupakan motivator untuk berwirausaha yang menyediakan pengalaman positif yang mempengaruhi intensi berwirausaha dan merupakan atribut lingkungan sosial individu.

Menurut Tung dan Yin (2011) mahasiswa yang memiliki figur kewirausahaan di dalam lingkungan keluarganya memiliki niat kewirausahaan yang lebih tinggi dibandingkan mahasiswa yang tidak memiliki figur kewirausahaan. Hal ini disebabkan oleh pengaruh yang berupa pengalaman positif yang diberikan figur kewirausahaan kepada mahasiswa. Pengalaman positif ini dapat berupa pengetahuan berwirausaha, cara menghadapi masalah, keuntungan berwirausaha, dan penglaman lainnya. Semakin kuat pengaruh positif figur kewirausahaan maka semakin tinggi niat kewirausahaan mahasiswa. Berdasarkan uraian tersebut maka hipotesis penelitian:

$\mathrm{H}_{3}$ : Terdapat pengaruh efikasi diri terhadap intensi kewirausahaan dengan lingkungan sosial sebagai variabel moderasi.

$\mathrm{H}_{4}$ : Terdapat pengaruh pendidikan terhadap intensi kewirausahaan dengan lingkungan sosial sebagai variabel moderasi.

\section{Pengaruh Efikasi Diri terhadap Intensi kewirausahaan}

Semakin kuat persepsi efikasi diri semakin giat dan tekun usaha-usahanya. Dengan demikian, efikasi diri akan karir seseorang dapat menjadi faktor penting dalam penentuan apakah intensi kewirausahaan seseorang sudah terbentuk pada tahapan awal seseorang memulai karirnya. Intensi kewirausahaan dipengaruhi efikasi diri, dimana pengaruhnya positif, semakin tinggi dukungan pada mahasiswa, maka semakin tinggi niat untuk berwirausaha, demikian pula semakin tinggi rasa percaya diri dan kematangan mental, maka semakin tinggi pula niat berwirausaha (Sri, 2013).

\section{Pengaruh Pendidikan terhadap Intensi kewirausahaan}

Menurut Tung dan Yin (2011), pendidikan akan meningkatkan efikasi kewirausahaan mahasiswa seperti mencari peluang, menggabungkan sumber daya, dan memimpin bisnis dengan sukses melalui sikap, pengetahuan dan keterampilan yang diberikan kepada mereka. Pendidikan juga dapat meningkatkan efikasi kewirausahaan mahasiswa melalui kegiatan pembelajaran, pengembangan rencana bisnis, menjalankan usaha kecil yang nyata, dan meningkatkan keinginan mereka untuk memulai usaha baru.

\section{Pengaruh Lingkungan Sosial terhadap Intensi Kewirausahaan}

Menurut Tung dan Yin (2011) mahasiswa yang memiliki figur kewirausahaan di dalam lingkungan keluarganya memiliki niat kewirausahaan yang lebih tinggi dibandingkan mahasiswa yang tidak memiliki figur kewirausahaan. Hal ini disebabkan oleh pengaruh yang berupa pengalaman positif yang diberikan figur kewirausahaan kepada mahasiswa. Pengalaman positif ini dapat berupa pengetahuan berwirausaha, cara menghadapi masalah, keuntungan berwirausaha, dan pengalaman lainnya. Semakin kuat pengaruh positif figur kewirausahaan maka semakin tinggi niat kewirausahaan mahasiswa

\section{METODE PENELITIAN}

Jenis penelitian yang dilakukan adalah penelitian kuantitatif asosiatif yaitu penelitian yang mencoba untuk mengetahui besarnya pengaruh efikasi diri dan pendidikan terhadap intensi kewirausahaan dengan lingkungan sosial sebagai variabel moderasi. Sumber data dalam penelitian ini adalah sumber data primer yang merupakan hasil kuesioner dari 200 mahasiswa Universitas Tarumanagara yang diberikan pertanyaan-pertanyaan yang 
berhubungan dengan variabel penelitian. Metode pengumpulan data yang digunakan dalam penelitian ini adalah dengan menggunakan kuesioner. Pertanyaan disusun berdasarkan operasionalisasi variabel penelitian dengan skor jawaban responden berdasarkan skala Likert dengan skor 1 sampai 5 yaitu $\mathrm{STS}=1 ; \mathrm{TS}=2 ; \mathrm{N}=3 ; \mathrm{S}=4 ; \mathrm{SS}=5$.

Independen variable dalam penelitian ini adalah efikasi diri (X1) dan pendidikan (X2). Dependent variable pada penelitian ini adalah Intensi kewirausahaan (Y). Moderating variable pada penelitian ini adalah lingkungan sosial (X3). Moderating variabel (X3) yaitu variabel independen yang akan mempekuat atau memperlemah hubungan antara variabel independen lainnya terhadap variabel dependen. Metode analisis yang digunakan untuk penelitian ini adalah analisis Regresi Linier berganda dengan variabel moderating.

\section{HASIL ANALISIS DATA}

\section{Hasil Analisis Validitas dan Reliabilitas}

Hasil uji validitas menunjukkan setiap butir pertanyaan mengenai efikasi diri, pendidikan, lingkungan sosial dan intensi kewirausahaan memiliki nilai korelasi lebih besar daripada 0,3 . Nilai - nilai korelasi tersebut menyatakan bahwa semua instrumen penelitian sudah valid.

Hasil uji reliabilitas menunjukkan variabel efikasi diri, pendidikan, lingkungan sosial dan intensi kewirausahaan memiliki nilai alpha cronbach diatas 0,70 yang berarti instrumen penelitian atau kuesioner sudah reliabel.

\section{Deskripsi Subjek Penelitian}

Rata-rata responden adalah berjenis kelamin pria 150 orang atau $75 \%$, sedangkan yang berjenis kelamin wanita sebanyak 50 orang atau $25 \%$. Dengan demikian maka rata-rata responden adalah pria. Rata-rata responden adalah usia kurang atau sama dengan 20 tahun. sebanyak 180 responden atau sebesar 90\%, sedangkan usia 21-26 tahun 20 orang atau $10 \%$.

Hasil penelitian menunjukkan bahwa seluruh data pada model regresi terdistribusi normal, tidak terdapat multikolinearitas pada model regresi dan tidak terdapat heteroskedastisitas dalam model regresi.

\section{Hasil Uji Hipotesis 1 dan 2}

Tabel Regresi Berganda tanpa Variabel Moderasi

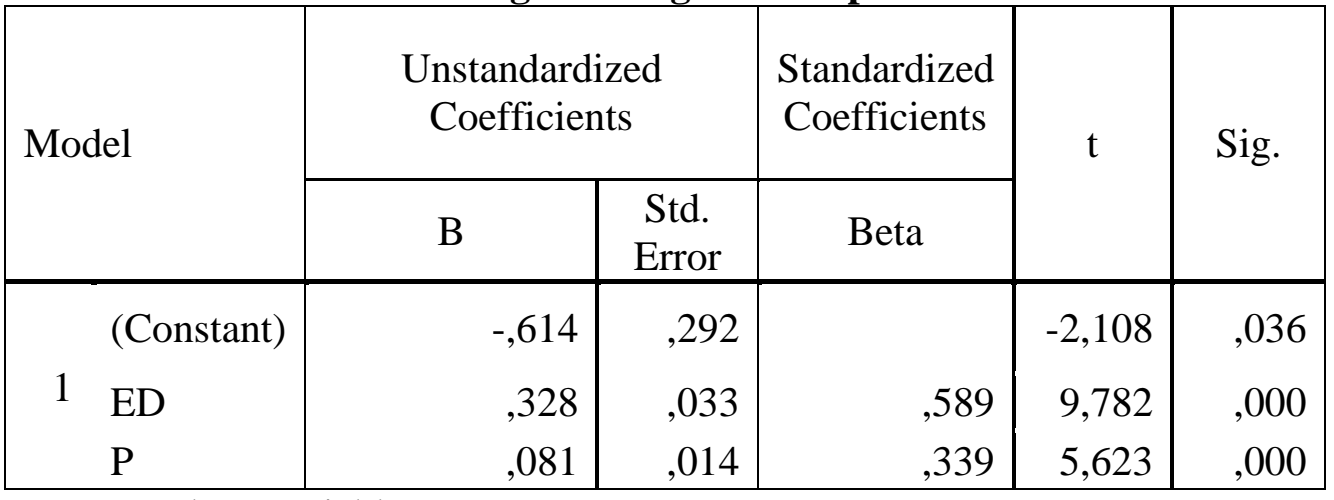

a. Dependent Variable: IK

Berdasarkan hasil analisis regresi berganda, didapat nilai signifikansi ED sebesar 0,000 untuk pengaruh efikasi diri terhadap intensi kewirausahaan yang artinya sig < 0,05. Oleh karena itu terdapat pengaruh efikasi diri terhadap intensi kewirausahaan, sedangkan nilai signifikansi $\mathrm{P}$ sebesar 0,000 untuk pengaruh pendidikan terhadap intensi kewirausahaan yang artinya sig < 0,05. Oleh karena itu terdapat pengaruh pendidikan terhadap intensi kewirausahaan. 
Berdasarkan hasil analisis data dan pengujian hipotesis dalam penelitian ini, dapat disimpulkan bahwa terdapat pengaruh yang signifikan efikasi diri dan pendidikan terhadap intensi kewirausahaan. Hasil ini sesuai dengan penelitian Ekpe dan Mat (2012). Hasil penelitian Ekpe dan Mat (2012) menyimpulkan bahwa orientasi kewirausahaan (efikasi diri dan pendidikan) memiliki pengaruh yang signifikan terhadap wirausaha di kalangan mahasiswi.

\section{Hasil Uji Hipotesis 3 dan 4}

\section{Tabel Hasil Regresi Berganda dengan Variabel Moderasi}

\begin{tabular}{|c|c|c|c|c|c|c|}
\hline \multirow{2}{*}{\multicolumn{2}{|c|}{ Model }} & \multicolumn{2}{|c|}{$\begin{array}{c}\text { Unstandardized } \\
\text { Coefficients }\end{array}$} & \multirow{2}{*}{$\begin{array}{c}\begin{array}{c}\text { Standardized } \\
\text { Coefficients }\end{array} \\
\text { Beta }\end{array}$} & \multirow{2}{*}{$\mathrm{t}$} & \multirow{2}{*}{ Sig. } \\
\hline & & B & $\begin{array}{l}\text { Std. } \\
\text { Error }\end{array}$ & & & \\
\hline \multirow{6}{*}{1} & (Constant) & $-2,629$ & 1,163 & & $-2,261$ &, 025 \\
\hline & ED &,- 297 & , 152 &,- 534 & $-1,955$ &, 052 \\
\hline & $\mathrm{P}$ & ,399 & ,074 & 1,666 & 5,413 & ,000 \\
\hline & LS & ,213 & , 163 &, 184 & 1,314 & , 190 \\
\hline & EDLS & ,079 & ,019 & 1,831 & 4,180 & ,000 \\
\hline & PLS &,- 039 & ,009 & $-2,248$ & $-4,317$ &, 000 \\
\hline
\end{tabular}

a. Dependent Variable: IK

Berdasarkan hasil analisis yang dengan variabel moderasi, didapat nilai signifikansi EDLS sebesar 0,000 yang artinya sig < 0,05, artinya terdapat pengaruh efikasi diri terhadap intensi kewirausahaan dengan lingkungan sosial sebagai variabel moderasi, sedangkan nilai signifikansi PLS sebesar 0,000 yang artinya sig < 0,05, artinya terdapat pengaruh pendidikan terhadap intensi kewirausahaan dengan lingkungan sosial sebagai variabel moderasi. Persamaan regresi yang diperoleh dari penelitian ini adalah:

$$
Y^{\prime}=-2,629-0,297 \mathrm{ED}+0,399 \mathrm{P}+0.213 L S+0,079 \mathrm{EDLS}-0,039 \mathrm{PLS}
$$

\section{Hasil Koefisien Determinasi}

Tabel Koefisien Determinasi tanpa Variabel Moderasi Model Summary ${ }^{\mathrm{b}}$

\begin{tabular}{|l|r|r|r|r|}
\hline Model & $\mathrm{R}$ & R Square & Adjusted R Square & \multicolumn{2}{c|}{$\begin{array}{c}\text { Std. Error of the } \\
\text { Estimate }\end{array}$} \\
\hline 1 &, $895^{\mathrm{a}}$ &, 802 &, 800 & 1,041 \\
\hline
\end{tabular}

a. Predictors: (Constant), P, ED, b. Dependent Variable: IK

Berdasarkan hasil koefisien determinasi sebelum adanya variabel moderasi, adjusted $\mathrm{R}$ square adalah 0,80 artinya sebesar $80 \%$ variasi intensi kewirausahaan dapat dijelaskan oleh variabel efikasi diri dan pendidikan, sisanya dijelaskan oleh variabel lain.

Tabel Koefisien Determinasi dengan Variabel Moderasi 
Model Summary

\begin{tabular}{|l|r|r|r|r|}
\hline Model & $\mathrm{R}$ & R Square & Adjusted R Square & \multicolumn{2}{|c|}{$\begin{array}{c}\text { Std. Error of the } \\
\text { Estimate }\end{array}$} \\
\hline 1 &, $907^{\mathrm{a}}$ &, 822 &, 818 &, 993 \\
\hline
\end{tabular}

a. Predictors: (Constant), PxLS, ED, LS, P, EDxLS

Setelah dilakukan moderasi, didapat koefisein determinasi adjusted $\mathrm{R}$ square adalah 0,818 artinya sebesar $81,8 \%$ variasi intensi kewirausahaan dapat dijelaskan oleh variabel efikasi diri dan pendidikan serta penambahan variabel moderasi lingkungan sosial, sisanya dijelaskan oleh variabel lain.

Berdasarkan hasil koefisein determinasi adjusted $\mathrm{R}$ square tesebut, maka variabel lingkungan sosial dapat digunakan sebagai variabel moderasi karena terbukti dapat meningkatkan nilai adjusted $\mathrm{R}$ square dari $80 \%$ menjadi $81.8 \%$.

\section{KESIMPULAN}

Berdasarkan penelitian dan pembahasan yang telah dijelaskan pada analisis data maka dapat diambil beberapa kesimpulan sebagai berikut:

1. Terdapat pengaruh efikasi diri terhadap intensi kewirausahaan.

2. Terdapat pengaruh pendidikan terhadap intensi kewirausahaan.

3. Terdapat pengaruh efikasi diri terhadap intensi kewirausahaan dengan lingkungan sosial sebagai variabel moderasi.

4. Terdapat pengaruh pendidikan terhadap intensi kewirausahaan dengan lingkungan sosial sebagai variabel moderasi.

\section{SARAN}

Saran yang bisa diberikan pada penelitian ini adalah :

1. Variabel efikasi diri dan pendidikan dapat digunakan sebagai prediktor intensi kewirausahaan.

2. Variabel lingkungan sosial dapat digunakan sebagai variabel moderasi antara variabel efikasi diri dan pendidikan terhadap intensi kewirausahaan.

3. Penambahan variabel yang relevan sangat disarankan untuk penelitian selanjutnya agar dapat memberikan kontribusi terhadap penelitian mengenai faktor yang mempengaruhi intensi kewirausahaan.

4. Penambahan sampel penelitian dapat memberikan hasil yang berbeda sehingga dapat memberikan kontribusi penelitian mengenai intensi kewirausahaan.

\section{DAFTAR PUSTAKA}

Alwisol. (2011). Psikologi Kepribadian. Malang: UMM Press.

Armitage, C.J dan Conner, M. (1999). The Theory of Planned Behaviour: Assesment of Predictive Validity and Perceive Control. British Journal of Social Psychology 38: 3554

Eka Aprilianty. (2012). Pengaruh Potensi Kepribadian Wirausaha, Pengetahuan Kewirausahaan dan Lingkungan. Jurnal Pendidikan Vokasi, Vol. 2 No. 3.

Ekpe, Isidore dan Mat, Norsiah. (2012). The Moderating Effect of Social Environment on the Relationship between Entrepreneurial Orientation of Female Students at Nigerian Universities. International Journal of Management Sciences and Business Research, Vol. 1, No. 4. 
King, Laura A. (2010).Psikologi Umum. (Alih Bahasa: Brian Marwendys). Jakarta: Salemba Humanika

Lee, Lena et. al. (2011). Entrepreneurial Intentions: The Influence of Organizational and Individual Factors. Journal of Business Venturing 26.

Linan, F. (2004). Intention-based models of entrepreneurship education. Piccolla Impresa/Small Business, Iss. 3: 11-35.

Nurul Indarti \& Rokhima Rostiani. (2008). "Intensi Kewirausahaan Mahasiswa: Studi Perbandingan Antara Indonesia, Jepang dan Norwegia." Jurnal Ekonomika dan Bisnis Indonesia.(Vol. 23, No. 4).

Rano Aditia Putra. (2012). Faktor-faktor Penentu Minat Mahasiswa Manajemen untuk Berwirausaha. Jurnal Manajemen, Vol. 1, No. 1.

Retno K., Susilaningsih, dan Sri S. (2013). Faktor-faktor yang memengaruhi Minat Berwirausaha pada Mahasiswa Program Studi Pendidikan Ekonomi FKIP UNS. Jupe UNS, Vol. 2, No. 1.

Retno B L dan Trisnadi W. (2012). Pengaruh Pendidikan Kewirausahaan terhadap Minat Berwirausaha Mahasiswa di STIE MDP, STMIK MDP, dan STIE MUSI. Jurnal Ilmiah STIE MDP.

Sang, M L; Daesung, C; Seong B L. (2005). Impact of Entrepreneurship Education. International Entrepreneurship and Management Journal 1.

Sarwono N. dan Arif J. S. N. (2013). Analisis Pengaruh Interaksi Pengetahuan Kewirausahaan dan Efikasi Diri terhadap Intensi Kewirausahaan. Kiat BISNIS, Vol. 5, No. 2.Sri Defriana. (2013). Pengaruh Sikap (Attitude) terhadap Persepsi Kelayakan (Perceived Feasibility) Berwirausaha dan Dampaknya terhadap Intensi Berwirausaha Mahasiswa. Jurnal Kewirausahaan, Vol. 1, No. 2.

Suryana. (2009). Kewirausahaan Pedoman Praktis: Kiat dan Proses Menuju Sukses. Jakarta: Salemba Empat

Tung, Moi and Yin, Lin Adeline. (2011). Young Adult Responses to Entrepreneurial Intent. Journal of Arts, Science \& Commerce Vol 2 No 3.

Yuyus Suryana \& Kartib Bayu. (2011). Kewirausahaan : Pendekatan Karakteristik Wirausahawan Sukses . Jakarta: Prenada Media Group

Zimmerer, Scarborough, \&Wilson. (2008). Kewirausahaan dan Manajemen Usaha Kecil Buku 1. (Alih Bahasa: Deny Arnos K dan Dewi Fitriasari). Jakarta: Salemba Empat. 
